${ }^{\odot}$ Н. В. Литвин, Н. І. Геник

\author{
ДВНЗ «Івано-Франківсъкий нащіональний медичний університет»
}

\title{
ОЦІНКА ПРИЧИН РАННІХ ВТРАТ ВАГІТНОСТІ У ЖІНОК ІЗ БЕЗПЛІДДЯМ, ВКЛЮЧЕНИХ У ПРОГРАМУ ДОПОМІЖНИХ РЕПРОДУКТИВНИХ ТЕХНОЛОГІЙ
}

Мета дослідження - оцінка перебігу першого триместру вагітності у пацієнток із лікованим безпліддям, включених у програму допоміжних репродуктивних технологій та визначення провідних етіологічних чинників, що обумовлюють розвиток локального непрогресуючого відшарування хоріона та ранні репродуктивні втрати.

Матеріали та методи. Проведено ретроспективний аналіз 1864 карт стаціонарних хворих із загрозою переривання вагітності та діагностованим початковим мимовільним викиднем, які перебували на лікуванні у відділеннях невиношування, гінекологічному відділенні міського пологового будинку м. Івано-Франківськ, а також у гінекологічному відділенні Прикарпатського центру репродукції людини за період 2011-2016 років. У контрольну групу увійшли 100 здорових вагітних. У 698 випадках пацієнтки були включені у програму допоміжних репродуктивних технологій. У 542 випадках (37,44 \%) було діагностовано ретрохоріальні гематоми, з них у 196 пацієнток (36,16 \%) (основна група) - із заплідненням in vitro, у 346 випадках (група порівняння) - при вагітності, яка настала у фрізіологічному циклі.

Результати дослідження та їх обговорення. Отримані нами дані щодо віку пацієнток досліджуваних груп дозволили припустити ризик виникнення ретрохоріальної гематоми частіше у юних пацієнток та жінок віком старше 30 років, вагомим чинником також був і паритет вагітностей. Результати проведеного клініко-анамнестичного аналізу продемонстрували переважання гестаційних втрат у терміни 5-7 тижнів вагітності (63,41 \%). У структурі причин ранніх викиднів анатомічні фрактори складали 18,08 \%, гормональні порушення - 36,53 \%, вроджені та набуті тромбофрілічні стани, включаючи аутоімунні і генетичні, відмічено у 27,30 \%, особливості каріотипу подружжя - у 10,33 \% спостережень, інсрекційно-запальний фактор - у 63,83 \% пацієнток. Доведено значиму роль інфекційного фрактора в генезі репродуктивних втрат: при гістологічному дослідженні виявлено морфологічні ознаки хронічного ендометриту (62,19 \%), висхідного інсрекційного ураження плідного яйця (54,87 \%), гравідарної гіпоплазії ендометрія (20,91 \%). Одним із важливих факторів розвитку ретрохоріальних гематом у жінок із лікованим безпліддям може слугувати ендокринний дисбаланс, встановлений у даної категорії пацієнток, який проявляється зростанням частки оперативних втручань на органах малого таза, високим відсотком нейроендокринних розладів у вигляді порушень менструального циклу, оваріальної диссрункції, недостатності лютеїнової фрази та гіпоестрогенного гормонального фону у жінок даної категорії.

Висновки. Невиношування вагітності у першому триместрі у жінок із лікованим безпліддям $є$ достатньо серйозною патологією, вагомість якої набуває особливого значення у випадку лікованого непліддя та використання допоміжних репродуктивних технологій, що вимагає поглибленого обстеження пацієнток для вияснення імовірних причин ранніх репродуктивних втрат та відкриває перспективи подальших досліджень.

Ключові слова: безплідність; невиношування вагітності; ретрохоріальна гематома; допоміжні репродуктивні технології; фрактори ризику.

ОЦЕНКА ПРИЧИН РАННИХ ПОТЕРЬ БЕРЕМЕННОСТИ У ЖЕНЩИН С БЕСПЛОДИЕМ, ВКЛЮЧЕННЫХ В ПРОГРАММУ ВСПОМОГАТЕЛЬНЫХ РЕПРОДУКТИВНЫХ ТЕХНОЛОГИЙ

Цель исследования - оценка хода первого триместра беременности у пациенток с бесплодием, включенных в программу вспомогательных репродуктивных технологий, и определение ведущих этиологических фракторов, обусловливающих развитие локального непрогрессирующего отслоения хориона и ранние репродуктивные потери.

Материалы и методы. Проведен ретроспективный анализ 1864 карт стационарных больных с угрозой прерывания беременности и диагностированным начальным самопроизвольным выкидышем, которые находились на лечении в отделениях невынашивания, гинекологическом отделении городского роддома г. Ивано-Франковск, а также в гинекологическом отделении Прикарпатского центра репродукции человека за период 2011-2016 гг. В контрольную группу вошли 100 здоровых беременных. В 698 случаях пациентки были включены в программу вспомогательных репродуктивных технологий. В 542 случаях (37,44 \%) были диагностированы ретрохориальные гематомы, из них в 196 пациенток (36,16 \%) (основная группа) с оплодотворением in vitro, в 346 случаях (группа сравнения) - при беременности, наступившей в фризиологическом цикле.

Результаты исследования и их обсуждение. Полученные нами данные относительно возраста пациенток исследуемых групп позволили предположить риск возникновения ретрохориальной гематомы чаще у молодых пациенток и женщин в возрасте старше 30 лет, весомым фрактором также был и паритет беременностей. Результаты проведенного клинико-анамнестического анализа продемонстрировали преобладание гестационных потерь в сроки 5-7 недель беременности (63,41 \%). В структуре причин ранних выкидышей анатомические фракторы составляли 18,08 \%, гормональные нарушения - 36,53 \%, врожденные и приобретенные тромбофрилические состояния, включая аутоиммунные и генетические, отмечено в 27,30 \%, особенности кариотипа супругов - в 10,33 \% наблюдений, инфекционно-воспалительный фрактор - в 63,83 \% пациенток. Доказано значимую роль инфекционного фрактора в генезисе репродуктивных потерь: при гистологическом исследовании обнаружены морфологические признаки хронического эндометрита (62,19 \%), восходящего инфекционного поражения плодного яйца (54,87 \%), гравидарной гипоплазии эндометрия (20,91 \%). Одним из важных факторов развития ретрохориальных гематом у женщин с бесплодием может служить эндокринный дисбаланс, установленный в данной категории пациенток, который проявляется ростом доли оперативных вмешательств на органах малого таза, высоким процентом нейроэндокринных расстройств в виде нарушений менструального цикла, овариальной дисфункции, недостаточности лютеиновой фразы и гипоэстрогенного гормонального фона у женщин данной категории. 
Выводы. Невынашивание беременности в первом триместре у женщин с бесплодием является достаточно серьезной патологией, значение которой приобретает особое значение в случае леченого бесплодия и использования вспомогательных репродуктивных технологий, требует углубленного обследования пациенток для выяснения возможных причин ранних репродуктивных потерь и открывает перспективы дальнейших исследований.

Ключевые слова: бесплодие; невынашивание беременности; ретрохориальная гематома; вспомогательные репродуктивные технологии; фракторы риска.

\section{ASSESSMENT OF CAUSES OF EARLY PREGNANCY LOSS IN WOMEN WITH INFERTILITY INCLUDED IN THE PRO-} GRAM OF ASSISTED REPRODUCTIVE TECHNOLOGIES

The aim of the study - to evaluate the course of the first trimester of pregnancy in patients with infertility, included in the program of assisted reproductive technologies and to identify the principal etiological factors leading to the development of local non-progressive chorionic detachment and early reproductive loss.

Materials and Methods. A retrospective analysis of 1864 medical charts of patients with threatening miscarriages and diagnosed primary spontaneous abortion had been carried out. These women had been treated at the Gynaecological Department of the City Maternity Hospital (Ivano-Frankivsk), and in the Gynaecological Department of Pre-Carpathian Centre for Human Reproduction for the period of 2011-2016. The control group consisted of 100 healthy pregnant women. In 698 cases, the patients were included in the program of assisted reproductive technologies. In 542 cases (37.44\%) patients suffered from subchorionic hematoma, 196 of them (36.16\%) (principal group) were fertilized in vitro; in 346 cases (comparison group) pregnancy occurred in physiological cycle.

Results and Discussion. The obtained data on the patients' age in the study groups made possible to assume the risk of subchorionic hematoma more often in young patients and women over the age of 30 years; the parity of pregnancies was also of great significance. The results of clinical and anamnestic analysis showed the prevalence of gestational losses in terms of 5-7 weeks of pregnancy (63.41\%). Among the causes of early abortions - anatomical factors accounted for $18.08 \%$, hormonal disorders $-36.53 \%$, congenital and acquired thrombophilic states (including autoimmune and genetic disorders) were observed in $27.30 \%$, peculiarities of couple karyotype - in $10.33 \%$ of cases, infectious inflammatory factor - in $63.83 \%$ of patients. A significant role of infectious factor in the genesis of reproductive losses was proved: histological examination revealed morphological signs of chronic endometritis (62.19\%), rising infectious lesions of fertilized eggs (54.87\%), endometrial hypoplasia (20.91 \%). One of the important factors of subchorionic hematoma development in women with treated infertility can be endocrine imbalance, diagnosed in this category of patients, which manifests itself as growing proportion of surgical interventions on the pelvic organs, a high percentage of neuroendocrine disorders, such as menstrual disorders, ovarian dysfunction, luteal phase deficiency and hypoestrogenic endocrine profile in women of this category.

Conclusions. Basing on the analysis, we can summarize that miscarriages in the first trimester in women with treated infertility is a very serious pathology, the seriousness of which is obvious in the case of treated infertility and applying of assisted reproductive technologies, which requires a meticulous examination of patients for revealing probable causes of early reproductive losses and opens a prospect for further research.

Key words: infertility; miscarriage; subchorionic hematoma; assisted reproductive technologies; risk factors.

ВСТУП. Невиношування вагітності - проблема, значення якої не тільки не применшується $з$ плином часу, але i, без сумніву, зростає. Залишається актуальною і проблема ранніх репродуктивних втрат як найбільш частого ускладнення гестаційного процесу без тенденції до зниження. Згідно з літературними повідомленнями, частота мимовільного переривання вагітності складає 20-25 \%, при цьому до 80 \% втрат припадає на перший триместр [1-4].

Із зростаючим впровадженням допоміжних репродуктивних технологій (ДРТ) проблема невиношування вагітності відкривається у нових аспектах, а збільшення числа невдалих спроб запліднення in vitro ряд авторів тісно пов'язує з імунопатологічними порушеннями [5-7]. У даний час вважається загальновизнаним, що порушення процесів інвазії трофобласта в першому триместрі вагітності приводять не тільки до ранніх репродуктивних втрат, але і до реалізації пізніх гестаційних ускладнень: затримки внутрішньоутробного розвитку плода, прееклампсії, передчасних пологів, відшарування плаценти, що, без сумніву, підвищує перинатальну та материнську смертність [8]. 3 іншої сторони, повноцінна плацентація створює необхідні умови для успішного пролонгування та завершення вагітності. Частота локального відшарування хоріона як одного з основних клінічних симптомів, що супроводжує ранні репродуктивні втрати, за останні десятиріччя суттєво не змінилася, причому провідним залишається твердження, що в основі матково-плацентарної апоплексії лежать зміни, які відбуваються в усьому організмі, а маткова-плацентарна геморагія $€$ тільки частковим їх проявом [9-12].

На сьогодні проведено достатньо вагоме число досліджень щодо визначення факторів ризику локального непрогресуючого відшарування хоріона в пацієнток, включених у програму ДРТ, однак у даний час недостатньо вивчено прогностичні можливості та не сорормовано чітко критерії формування груп підвищеного ризику [5, $10,13]$. Відсутність своєчасної діагностики і, як результат, лікувальні заходи, що проводять тільки при встановленні факту вагітності, часто $€$ неефективними, обумовлюючи зростання частки ранніх репродуктивних втрат. У зв'язку з вищевикладеним, автори єдині в думці, що при наявності ретрохоріальних гематом наобхідно розпочинати обстеження та лікування подружньої пари, в тому числі й імунокорекцію до діагностики вагітності, на етапі включення у програму ДРТ. Тому ретельний скринінг, моніторинг клініко-лабораторних показників та оптимальна передгестаційна підготовка жінок із ранніми репродуктивними втратами в анамнезі не тільки попереджують ранні викидні, але і сприяють реабілітації репродуктивної функції жінок в цілому, попереджуючи акушерські ускладнення у другій половині вагітності $[11,14]$. 
Вищевикладене дозволило сорормувати мету даного дослідження.

META ДОсЛІДЖЕННЯ - оцінка перебігу першого триместру вагітності у пацієнток із лікованим безпліддям, включених у програму допоміжних репродуктивних технологій, та визначення провідних етіологічних чинників, що обумовлюють розвиток локального непрогресуючого відшарування хоріона та ранні репродуктивні втрати.

МАТЕРІАЛИ ТА МЕТОДИ. Проведено ретроспективний аналіз 1864 карт стаціонарних хворих із загрозою переривання вагітності та діагностованим початковим мимовільним викиднем, які перебували на лікуванні у відділеннях невиношування, гінекологічному відділенні міського пологового будинку м. Івано-Франківськ, а також у гінекологічному відділенні Прикарпатського центру репродукції людини за період 2011-2016 років. У контрольну групу увійшли 100 здорових вагітних. Слід відмітити, що у 698 випадках пацієнтки були ліковані з приводу непліддя із застосуванням допоміжних репродуктивних технологій. У 542 випадках $(37,44 \%)$ було діагностовано ретрохоріальні гематоми, з них у 196 пацієнток (36,16 \%) (основна група) - із заплідненням in vitro, у 346 випадках (група порівняння) - при вагітності, яка настала у фрізіологічному циклі.

РЕЗУЛЬТАТИ ДОСЛІДЖЕННЯ ТА ЇХ ОБГОВОРЕННЯ. Вік вагітних коливався від 18 до 45 років $((29 \pm 5,06)$ року), але найбільша питома вага відмічена у віці від 21 до 35 років (417 - 76,94 \%). Отримані нами дані щодо віку пацієнток досліджуваних груп дозволили припустити ризик виникнення ретрохоріальної гематоми частіше у юних пацієнток (16,32 \% - в основній групі проти 4,62 \% - у групі порівняння) та жінок віком старше 30 років $(38,77 \%$ проти 16,18 \% відповідно). Вагомим чинником також був і паритет вагітностей - ризик локального відшарування хоріона прогресивно збільшувався із зростанням кількості вагітностей в анамнезі (більше трьох епізодів пологів в анамнезі, звикле невиношування, більше трьох абортів (штучних та самовільних) тощо).

Наші спостереження відмітили найбільшу частку ретрохоріальних гематом у терміни $(9,2 \pm 1,2)$ тижня (368$67,89 \%)$, при цьому, як правило, спостерігався крайовий супрацервікальний варіант локалізації гематоми (у 291 жінки із 542 випадків - 53,69 \%), субхоріальний варіант відмічено у 152 жінок (28,04 \%), субамніотичний варіант - у 99 пацієнток (18,27 \%). Крайовий та субхоріальний варіанти відшарування супроводжувалися клінічною симптоматикою загрози переривання вагітності у вигляді кров'янистих виділень, субхоріальному варіанту передували прояви загрози переривання вагітності; безсимптомний перебіг відмічено у половині випадків при субамніотичному варіанті.

Характеризуючи наслідки перебігу вагітності у першому триместрі, слід відмітити їх пряму залежність від об'єму гематоми. У 64,94 \% випадків відмічено об'єм гематоми в межах до $(9,8 \pm 1,2)$ см³ $^{3}$, у кожної четвертої пацієнтки - більше 25 см $^{3}$ - у 146 (26,93 \%) спостережень. При крайовій супрацервікальній локалізації гематоми з незначними кров'янистими виділеннями вагітність прогресувала у 77,76 \% випадків, у 67 випадках (23,02 \%) відбувся мимовільний викидень. При цьому відмічено достовірно вищий об'єм гематоми (в середньому $(15,6 \pm 5,2)$ см$\left.^{3}\right)$, ніжпривагітності, яказбереглася (всередньому $(5,8 \pm 4,6)$ см³) $^{3}$ $(p<0,05)$. При субхоріальній локалізації гематоми в біль- шості пацієнток (101 із 152 осіб - 66,44 \%) зареєстровано незначну кількість кров'янистих виділень, при цьому у 24 випадках $(15,76$ \%) вагітність закінчилася мимовільним перериванням. При субамніотичному варіанті гематоми вагітність збереглася у 92,92 \% випадків.

Характеризуючи швидкість регресу гематом у жінок основної групи, слід відмітити її межі у середньому від 8 до 26 днів, причому при супрацервікальній крайовій локалізації гематоми, а також субамніотичному варіанті у більшості випадків спостерігалось її зникнення (очевидно, за рахунок можливості ії спорожнення через цервікальний канал, що сприяє більш швидкому регресу гематоми), у 19,93 \% випадків виявлено ознаки так званої «організації» гематоми, у 6,18 \% - гематома збільшилася удвічі за об'ємом, у 9,62 \% -ії локалізація змінилася на субхоріальну. У випадку субхоріального розміщення гематоми найчастіше спостерігалась іiі «організація» - у 56,57 \%, повне ії зникнення відмічалось у 10 вагітних $((17,86 \pm 5,12) \%)$, у 17,11 \% - розміщення гематоми змінилося на супрацервікальну локалізацію, і у 10,52 \% були відсутні ознаки «організації» та збільшився об'єм гематоми.

Враховуючи подані вище результати, слід вказати, що вирішальним для наслідків вагітності є власне об'єм гематоми, тоді як локалізація $€$ не настільки вагомою для оцінки імовірного негативного завершення гестації.

Термін появи ретрохоріальної гематоми в основній групі відмічений від 4 до 16 тижнів, при цьому у 82,65 \% (162) випадків були виявлені у терміні від 4 до 8 тижнів вагітності. Загибель ембріона спостерігалася у 82 жінок (41,83 \%), при цьому анембріонія - у 28 (34,14 \%) випадках. Результати проведеного клініко-анамнестичного аналізу продемонстрували переважання гестаційних втрат у терміни 5-7 тижнів вагітності - 52 (63,41 \%).

У 24 випадках $(29,27$ \%) було проведено евакуацію плідного яйця із використанням медикаментозного методу, у 58 осіб (70,73 \%) - шляхом інструментального спорожнення порожнини матки з використанням вакуум-аспірації. Звертають на себе увагу результати гістологічного дослідження, представлені у 95,12 \% некрозом децидуальної тканини, висхідним інсекційним ураженням плідного яйця (54,87 \%) та ознаками дифузного ендометриту (62,19 \%).

Ретельний аналіз акушерсько-гінекологічного анамнезу пацієнток із ретрохоріальними гематомами та жінок групи порівняння і контрольної групи продемонстрував, що аборти займали вагоме місце в анамнезі жінок із невиношуванням, при цьому два та більше інструментальних випадки переривання вагітності мали більше половини жінок $(p<0,05)$. Також слід відмітити у 23,97 \% випадків самовільні викидні та невдалі спроби запліднення in vitro, що удвічі частіше проти даних анамнезу пацієнток групи порівняння (р<0,001). У $112(20,99$ \%) випадках був встановлений діагноз «звикле невиношування», в 11 пацієнток $(2,21 \%)$ в анамнезі гістологічно підтверджено міхурцевий занесок.

Загалом у структурі причин ранніх викиднів у досліджуваних групах анатомічні фрактори складали 98 (18,08\%), гормональні порушення - 198 (36,53 \%), вроджені та набуті тромбофрілічні стани, включаючи аутоімунні і генетичні, відмічено у 148 (27,30 \%), особливості каріотипу подружжя - в 56 (10,33 \%) спостереженнях. Інфекційно-запальний фрактор як результат багаторазових репродуктивних не- 
вдач та внутрішньоматкових втручань діагностовано у 346 $(63,83 \%)$ пацієнток.

Найбільш поширеними гінекологічними захворюваннями були хронічні генітальні інфекції, які займали провідне місце щодо структурної значущості: це патологія шийки матки та запальні захворювання і оперативні втручання, причому їх частка втричі переважала показники в групі контролю та достовірно частіше відмічена у групі порівняння ( $<<0,05)$, що підтверджує провідну роль тривалої персистенції інфекційних чинників в основі безпліддя інсрекційного генезу з імовірним аутоімунним ураженням і порушенням циклічної трансформації та рецептивності ендометрія. Так, частота інфекцій, що передаються статевим шляхом, у досліджуваних групах перевищила частоту даного показника у контролі ( $<0,001)$, причому звертало на себе увагу переважання так званих мікст-інфекцій та вірусних чинників, які зустрічалися частіше в анамнезі й в основній групі, незважаючи на ретельне обстеження, лікування та інсекційний моніторинг на преконцепційному етапі.

При проведенні гістологічного дослідження в основній групі на етапі преконцепційного обстеження та підготовки відзначено ознаки хронічного ендометриту, гіперпластичні процеси міо-ендометрія, міоматозні зміни, у 20,91 \% - ультразвукові та морфологічні маркери так званого «тонкого» ендометрія, у 31,63 \% випадків - неповноцінну трансформацію ендометрія та невідповідність морфологічної структури фразі оваріально-менструального циклу. Слід відмітити позитивну кореляцію вказаних змін із частотою інструментальних втручань в анамнезі та високою часткою запальних процесів органів малого таза.

Порушення менструального циклу спостерігалися частіше у групі жінок із лікованим безпліддям, причому найбільш часто відмічено опсоменорею та олігоменорею ( $<<0,02)$, також значимою була частка альгодисменореї та гіперполіменореї без достовірних відмінностей $(p>0,05)$. Аналіз даних також продемонстрував, що прояви гіперандрогенії у пацієнток із заплідненням in vitro відмічено частіше у 2,1 раза, ніж у групі порівняння $(p<0,05)$. Без сумніву, що порушення біосинтезу та метаболізму андрогенів здійснює тривалий стійкий вплив на різні ланки репродуктивної системи організму жінки та супроводжує зростання частки ранніх репродуктивних втрат.

Особливості репродуктивного та акушерського анамнезу дозволили відмітити, що першовагітні жінки складали 149 випадків (27,49\%), повторновагітні - 393 (72,51 \%). Характеризуючи дітородну функцію, було відмічено у 319 осіб (58,85 \%) неускладнений перебіг пологів, 85 (15,68 \%) пацієнток були розроджені шляхом операції кесаревого розтину, у 62 (11,43 \%) випадках мали місце передчасні пологи. Ранній розрив плідних оболонок відмічено у 121 (22,32 \%) пацієнтки, у 38 (7,01 \%) випадках післяродовий період ускладнився кровотечею, а у 21 (3,87 \%) - метроендометритом. Перинатальні втрати (антенатальна загибель плода, інтранатальна та рання неонатальна смертність) відмічені у 27 випадках (4,98 \%).

Особливістю останніх років є збільшення питомої ваги поєднаної соматичної патології та все більш глибоке поширення в популяції екстрагенітальних захворювань так званого метаболічного синдрому із клінічними ознаками чітко визначеного симптомокомплексу [14]. Слід відмітити, що порушення жирового обміну та надмірна вага тіла у жінок, включених у програму допоміжних репродуктивних технологій, зустрічалося у 2,8 раза частіше, ніж у контрольній групі $(p<0,01)$. Звертає на себе увагу і частота міоми матки, яка, порівняно з контрольною групою, була відмічена у 2 рази частіше у жінок із заплідненням in vitro $(p<0,05)$. Вади розвитку матки у вигляді сідлоподібної матки та дворогої матки спостерігалися також із більшою часткою в основній групі порівняно з групою порівняння $(p>0,05)$. Слід відмітити зростання відсотка оперативних втручань на органах малого таза у пацієнток основної групи, які у 3,8 раза переважали показники у групі порівняння. Очевидним залишається фракт, що злукова хвороба, порушення кровопостачання придатків після операцій на маткових трубах, а також операційна травма яєчникової тканини, без сумніву, здійснювали свій пошкоджуючий вплив на параметри оваріального резерву та стероїдогенезу, що опосередковано змінювало гормональний фон та умови для фрізіологічного фрормування імплантаційного потенціалу ендометрія [6].

Отримані нами дані клініко-анамнестичних особливостей дозволили провести оцінку значимості провідних фракторів і прогнозувати ризик хоріональної дисфункції та ускладненого перебігу першого триместру гестації із локальним непрогресуючим відшаруванням хоріона. Все вищевикладене дозволяє припустити, що ретрохоріальні гематоми $€$ наслідком дії великої кількості патологічних причин із реалізацією різноманітних часто перехресних, патофрізіологічних шляхів, тому виділити домінуючий етіологічний фактор існуючими методами діагностики не завжди є можливим.

ВИСнОВкИ. Одним із важливих фракторів розвитку ретрохоріальних гематом у жінок із лікованим безпліддям може слугувати ендокринний дисбаланс, встановлений у даної категорії пацієнток, який проявляється зростанням частки оперативних втручань на органах малого таза, високим відсотком нейроендокринних розладів у вигляді порушень менструального циклу, оваріальної дисфункції, недостатності лютеїнової фрази та гіпоестрогенного гормонального фону у жінок даної категорії.

Результати проведеного клініко-анамнестичного аналізу продемонстрували переважання гестаційних втрат у терміни 5-7 тижнів вагітності (63,41\%). У структурі причин ранніх викиднів анатомічні фрактори складали 18,08 \%, гормональні порушення - 36,53 \%, вроджені та набуті тромбофілічні стани, включаючи аутоімунні і генетичні, відмічено у 27,30 \%, особливості каріотипу подружжя - в 10,33\% спостережень, інфекційно-запальний фрактор-у $63,83 \%$ пацієнток.

Доведено значиму роль інфекційного фрактора в генезі репродуктивних втрат: при гістологічному дослідженні виявлено морсологічні ознаки хронічного ендометриту (62,19\%), висхідного інфекційного ураження плідного яйця (54,87 \%), гравідарної гіпоплазії ендометрія $(20,91 \%)$.

ПЕРСПЕКТИВИ ПОДАЛЬШИХ ДОСЛІДЖЕНЬ. На основі проведеного аналізу можна зробити висновок, що невиношування вагітності у першому триместрі у жінок із лікованим безпліддям $€$ достатньо серйозною патологією, вагомість якої набуває особливого значення у випадку лікованого непліддя та використання допоміжних репродуктивних технологій, що вимагає поглибленого обстеження пацієнток для вияснення імовірних причин ранніх репродуктивних втрат та відкриває перспективи подальших досліджень. 


\section{СПИСОК ЛІТЕРАТУРИ}

1. Башмакова Н. В. Прогнозирование преждевременных родов у женщин с первичным и вторичным привычным невынашиванием беременности в анамнезе / Н. В. Башмакова, Е. А. Винокурова, О. А. Краева // Акушерство и гинекология. - 2012. - № 5. - С. 29-33.

2. Воропаева Е. Е. Самопроизвольный аборт в аспекте учения о патоморфозе / Е. Е. Воропаева // Урал. мед. журн. - 2011. - T. 79, № 1. - С. 95-100.

3. Меныпенина Т. А. Патогенетические аспекты и причины неразвивающейся беременности (обзор литературы) / Т. А. Меныпенина // Урал. мед. журн. - 2012. - Т. 98, № 6. - С. 15-20.

4. Тетруашвили Н. К. Гормональные причины привычного выкидыша, методы коррекции (клиническая лекция) / Н.К. Тетруашвили, А. А. Агаджанова // Гинекология. - 2012. - T. 14, № 3. - C. 47-59.

5. Герилович Л. А. Оценка состояния здоровья женщин, использующих программы вспомогательных репродуктивных технологий / Л. А. Герилович, А. Т. Егорова, М.И.Базина // Медицинский альманах. - 2015. - № 4. - С. 76-79.

6. Капустін Е. В. Місце та роль допоміжних репродуктивних технологій (ДРТ) у лікуванні непліддя та збереженні фертильності / Е. В. Капустін, Г.Й. Геревич // Акушерство. Гінекологія. Генетика. - 2016. - Т. 2, № 2. - С. 30-33.

7. Масло Д. М. Оптимізація тактики ведення вагітності та пологів у жінок після застосування допоміжних репродуктивних технологій / Д. М. Масло // Здоровье женщины. - 2016. - № 5. - C. 160-164.

\section{REFERENCES}

1. Bashmakova, N.V., Vynokurova, E.A., \& Kraeva, O.A. (2012). Prognozirovanie prezhdevremennyh rodov u zhenshchin s pervichnym i vtorichnym privychnym nevynashivaniem beremennosti $v$ anamneze [Prediction of preterm birth in women with primary and secondary recurrent miscarriage history] Akusherstvo i ginekologiya - Obstetrics and Gynecology, 5, 29-33 [in Russian].

2. Voropaeva, E.E. (2011). Samoproizvolnyi abort v aspekte ucheniya o patomorfoze [Spontaneous abortion in the aspect of the doctrine of pathomorphosis]. Ural. med. zhurn. - Ural. Med. Journal, 1 (79), 95-100 [in Russian].

3. Menypenyna, T.A. (2012). Patogeneticheskie aspekty prichiny nerazvivayushcheysia beremennosti (obzor literatury) [Pathogenetic aspects and causes of not developing pregnancy (review)]. Ural. med. zhurn. - Ural. Med. Journal, 6 (98), 15-20 [in Russian].

4. Tetruashvili, N.K., \& Agadzhanova, A.A. (2012). Gormonalnye prichiny privychnogo vykidysha, metody korrektsii (klinicheskaya lektsiya) [Hormonal causes of habitual abortion, the correction methods (clinical lecture)]. Ginekologiya - Gynecology, 3 (14), 47-59 [in Russian].

5. Gerilovich, L.A., Egorova, A.T., \& Bazina, M.I. (2015) Otsenka sostoyaniya zdorovya zhenshchin, ispolzuyushchikh programmy vspomogatelnyh reproduktivnyh tehnologiy [Evaluation of the health status of women using assisted reproductive technology programs]. Meditsinskiy almanakh - Medical Almanac, 4, 76-79 [in Russian].

6. Kapustin, E.V., \& Herevych, H.Y. (2016). Mistse ta rol dopomizhnykh reproduktyvnykh tekhnolohiy (DRT) u likuvanni nepliddya ta zberezhenni fertylnosti [The place and role of assisted reproductive technology (ART) in the treatment of infertility and
8. Perinatal outcomes in women with subchorionic hematoma: a systematic review and meta-analysis / M. G. Tuuli, S. M. Norman, A. O. Odibo [et al.] // Obstet. Gynecol. - 2011. Vol. 117. - P. 1205-1212.

9. Буштырева И. О. Прогностические маркеры ранних репродуктивных потерь у пациенток с ретрохориальной гематомой / И. О. Буштырева, Н. Б. Кузнецова, Т. А. Заманская // Акушерство и гинекология. - 2016. - № 1. - С. 28-32.

10. Волкова Е. В. Течение беременности, осложненное ретрохориальной гематомой в первом триместре / Е. В. Волкова, Л. Ф. Гайдамакина, А. И. Демидова // Фарматека. 2016. - № 12. - С. 53-55.

11. Кирющенков П. А. Патогенетическое обоснование тактики ведения отслойки хориона и плаценты на ранних сроках беременности / П. А. Кирющенков, Д. М. Белоусов, О. С. Александрита // Гинекология. - 2010. - № 1. - С. 36-39.

12. Торчинов А. М. Влияние ретрохориальной гематомы на исход беременности при привычном невынашивании / А. М. Торчинов, М. М. Умаханова, Г. Л. Доронин // Лечащий врач. - 2014. - № 12. - С. 12-16.

13. Subchorionic hematoma occurs more frequently in in vitro fertilization pregnancy / K. Asato, K. Mekaru, C. Heshiki [et al.] // Eur. J. Obstet. Gynecol. Reprod. Biol. - 2014. - Vol. 181. - P. 41-44.

14. Бугеренко Е. Ю. Прегравидарная подготовка пациенток с отягощенным акушерским анамнезом / Е. Ю. Бугеренко // Вопр. гинекологии, акушерства и перинатологии. - 2012. T. 11, № 3. - C. 18-24.

fertility preservation]. Akusherstvo. Hinekolohiya. Henetyka. Obstetrics. Gynecology. Genetics, 2(2),30-33 [in Ukrainian].

7. Maslo D.M. (2016). Optymizatsiya taktyky vedennya vahitnosti ta polohiv u zhinok pislya zastosuvannya dopomizhnykh reproduktyvnykh tekhnolohiy [Optimization tactics of pregnancy and childbirth in women after use of assisted reproductive technology]. Zdorovye zhenshchiny - Women's Health, 5, 160164 [in Ukrainian].

8. Tuuli, M.G., Norman, S.M., Odibo, A.O., Macones, G.A., Cahill, A.G. (2017). Perinatal outcomes in women with subchorionic hematoma: a systematic review and meta-analysis. Obstet. Gynecol.,117,1205-1212.

9. Bushtyreva, I.O., Kuznetsova, N.B., \& Zamanskaya T.A (2016). Prognosticheskie markery rannih reproduktivnyh poter u patsientok s retrohorialnoy gematomoy [Prognostic markers of early reproductive losses in patients with retrochorial hematoma]. Akusherstvo i ginekologiya - Obstetrics and Gynecology, 1, 28-32 [in Ukrainian].

10. Volkova, E.V., Gaydamakina, L.F., \& Demidova A.I. (2016). Techenie beremennosti, oslozhnennoe retrohorialnoy gematomoy v pervom trimestre [The course of pregnancy, complicated retrochorial hematoma in the first trimester]. Farmateka - Farmateka, 12, 53-55 [in Russian]

11. Kiriushhenkov, P.A., Belousov, D.M., \& Aleksandrita, O.S (2010). Patogeneticheskoe obosnovanie taktiki vedeniya otsloyki khoriona i placenty na rannikh srokakh beremennosti [Pathogenetic substantiation of tactics and chorionic detachment of the placenta in early pregnancy]. Ginekologiya-Gynecology,1, 36-39 [in Russian].

12. Torchinov, A.M., Umahanova, M.M., \& Doronin, G.L. (2014). Vliyanie retrohorialnoy gematomy na ishod beremen- 
nosti pri privychnom nevynashivanii [Influence of retrochorial hematoma on pregnancy outcome with habitual miscarriage] Lechashchiy vrach - Attending Doctor, 12, 12-16 [in Russian].

13. Asato, K., Mekaru, K., Heshiki, C., Sugiyama, H., Kinjyo, T., ... Masamoto, H. (2014). Subchorionic hematoma occurs more frequently in vitro fertilization pregnancy. Eur. J. Obstet. Gynecol. Reprod. Biol., 181, 41-44.
14. Bugerenko E. Yu. (2012). Pregravidarnaya podgotovka patsientok $s$ otyagoshchennym akusherskim anamnezom [Preparation before pregnancy of patients with complicated obstetric history]. Vopr. ginekologii, akusherstva i perinatologii - Questions of Gynecology, Obstetrics and Perinatology, 3 (11), 18-24 [in Russian].

Отримано 23.01.17 